\title{
Metabolism, Transport and Drug-Drug Interactions of Silymarin
}

\author{
Ying Xie *, Dingqi Zhang, Jin Zhang and Jialu Yuan \\ School of Pharmacy, Macau University of Science and Technology, Taipa, Macao 999078, China; \\ zhangdingqi1998@gmail.com (D.Z.); 1609853ppa11002@student.must.edu.mo (J.Z.); \\ 1609853dpa11001@student.must.edu.mo (J.Y.) \\ * Correspondence: yxie@must.edu.mo; Tel.: +853-88972426
}

Received: 27 September 2019; Accepted: 14 October 2019; Published: 14 October 2019

\begin{abstract}
Silymarin, the extract of milk thistle, and its major active flavonolignan silybin, are common products widely used in the phytotherapy of liver diseases. They also have promising effects in protecting the pancreas, kidney, myocardium, and the central nervous system. However, inconsistent results are noted in the different clinical studies due to the low bioavailability of silymarin. Extensive studies were conducted to explore the metabolism and transport of silymarin/silybin as well as the impact of its consumption on the pharmacokinetics of other clinical drugs. Here, we aimed to summarize and highlight the current knowledge of the metabolism and transport of silymarin. It was concluded that the major efflux transporters of silybin are multidrug resistance-associated protein (MRP2) and breast cancer resistance protein (BCRP) based on results from the transporter-overexpressing cell lines and MRP2-deficient $\left(\mathrm{TR}^{-}\right)$rats. Nevertheless, compounds that inhibit the efflux transporters MRP2 and BCRP can enhance the absorption and activity of silybin. Although silymarin does inhibit certain drug-metabolizing enzymes and drug transporters, such effects are unlikely to manifest in clinical settings. Overall, silymarin is a safe and well-tolerated phytomedicine.
\end{abstract}

Keywords: silybin/silymarin; metabolism; efflux transporters; drug-drug interaction (DDI)

\section{Introduction}

Silymarin, an extraction from the seeds of milk thistle (Silybum marianum), has been used for liver and gallbladder dysfunction in Europe for thousands of years [1,2]. Silybin, also known as silibinin, is the major bioactive flavonolignan in silymarin, comprising approximately $50-70 \%$ of the extract [3]. Naturally-occurring silybin is a mixture of two diastereomers named silybin A and silybin $B$ in approximately equal portions. They have configurations of $2 R, 3 R, 10 R, 11 R$ and $2 R, 3 R, 10 S, 11 S$, respectively, as shown in Figure 1 [4]. Other flavonolignans such as isosilybin A and B, silychristin, isosilychristin, silydianin, and silimonin are also present in silymarin [5].

In recent years, studies have demonstrated that the pharmacological effects of silymarin/silybin are not limited to the treatment of liver diseases. It also has equally promising effects in protecting the pancreas, kidney, myocardium, and central nervous system [6]. This is because silymarin/silybin has antioxidant, anti-inflammatory, protein synthesis-enhancing, and anti-fibrotic activities as well as a good safety profile [7-9]. Moreover, silymarin/silybin can inhibit gluconeogenesis and autophagy of pancreatic $\beta$-cells, and repair damaged cells, showing anti-diabetic effects $[10,11]$. Recently, studies further demonstrated the anti-cancer effects of silybin via regulating the cancer cell cycle, apoptosis and autophagy, as well as inhibiting tumor-inducing factors [12-14]. Moreover, it is interesting to note that silybin has potential therapeutic effects for Alzheimer's disease (AD) via counteracting the toxicity of $\mathrm{A} \beta$ (amyloid beta) [15] which is the central peptide responsible for AD [16]. 
Although preclinical pharmacological benefits of silymarin seem promising, few of them have manifested in the clinical studies. Higher-than-usual-dose silymarin failed to produce a satisfactory anti- hepatitis C virus (HCV) effect in a large randomized controlled trial [17]. This is possibly because of the poor bioavailability of silymarin, which led to plasma concentrations far below the levels used in in vitro experiments [18-20]. After absorption, silymarin undergoes rapid phase II metabolism and is primarily excreted into bile and urine. Moreover, it exhibits enhanced absorption in patients with hepatitis $\mathrm{C}$ and nonalcoholic fatty liver disease [21,22]. Therefore, understanding the metabolism and transport of silymarin will be important for improving its low bioavailability and resolving the inconsistencies in clinical outcomes as well as results of in vitro studies. Moreover, it is necessary to understand the risks of drug-drug interactions (DDIs) associated with the ingestion of silymarin/silybin, if there are any, in which a dose adjustment may be required.

The goal of the present paper is to summarize and highlight the current knowledge of the metabolism and transport of silymarin/silybin and drug-drug interactions mediated by metabolizing enzymes and transporters.<smiles></smiles>

\section{Silybin A}<smiles>COc1cc([C@@H]2Oc3cc([C@@H]4Oc5cc(O)cc(O)c5C(=O)[C@H]4O)ccc3O[Ge]2CO)ccc1O</smiles>

\section{Silybin B}

Figure 1. Chemical structures of silybin diastereomers.

\section{Metabolism and Transport of Silymarin}

Silymarin has oral absorption only about $23-47 \%$ and quick phase II conjugation, leading to low bioavailability, which has been reviewed [20]. Here, we would like to provide a more dedicated and up-to-date outlook on the metabolism and transport of silymarin.

\subsection{Absorption}

It is commonly agreed that silymarin suffers from low bioavailability due to poor solubility in water [1]. However, efflux transporters on the apical side of the intestinal epithelium further throttled the absorption of silybin as seen in Figure $2[19,23]$.

The Caco-2 cell monolayer model was used to investigate the intestinal absorption of silybin [23]. The measured mean efflux ratios of silybin A and silybin B were 5.05 and 4.61, respectively, indicating an active transport mechanism. Moreover, MK571 (a multidrug resistance-associated protein (MRP2)-specific inhibitor) significantly decreased the efflux ratio of silybin, while Ko143 
(a breast cancer resistance protein (BCRP)-specific inhibitor) and cyclosporin A (both a BCRP and P-glycoprotein (P-gp) inhibitor) were less potent, suggesting that intestinal efflux of silybin is mediated by MRPs and possibly BCRP. Studies carried out with Madin-Darby canine kidney cells II (MDCKII) lines overexpressing transporters (MRP2, BCRP, or MDR1) and a sandwich-cultured hepatocyte model confirmed that the transporters involved in the absorption and excretion of silybin are MRP2 and BCRP, but not P-gp [23], raising the question of whether inhibitors of these two transporters are likely to increase silybin absorption.

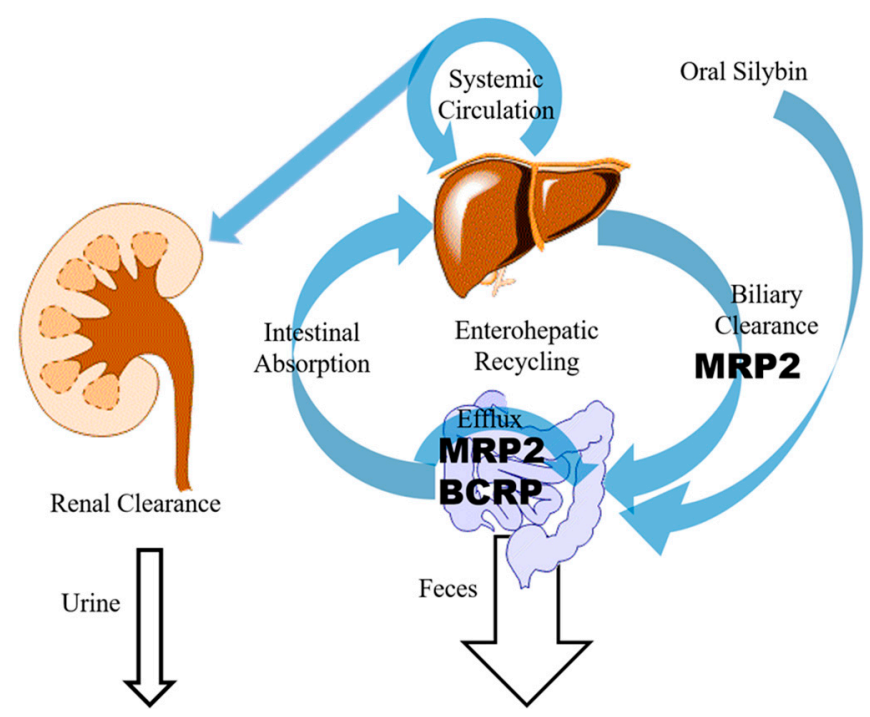

Figure 2. Transporters related to the disposition and elimination of silybin. BCRP: breast cancer resistance protein; MRP2: multidrug resistance-associated protein.

\subsection{Metabolism}

After oral administration, silybin/silymarin undergoes both phase I and phase II biotransformation, especially the latter [24]. Figure 3 shows that phase I metabolites of silybin mainly include O-demethylated ones mediated by the CYP2C8 (Cytochrome P450 Family 2 Subfamily C Member 8 ) isoenzyme [25]. In addition, four minor metabolites including three monohydroxy ones and one dihydroxy one are also observed, though their structures are not confirmed [26]. Silybin and its phase I metabolites undergo extensive phase II biotransformation, as most of the silybin in the system exists as conjugates including 55\% glucuronidated conjugates and about $28 \%$ sulfated ones [17,18].

Glucuronidation reactions of silybin are mediated by UDP-glucuronosyltransferase (UGT)1A1, 1A6, 1A7, 1A9, 2B7, and 2B15, while sulfidation reactions are mediated by sulfotransferases (SULTs) [27]. Four monoglucuronides, 1 diglucuronide, 3 monosulfates, 2 glucuronide sulfates, and $O$-demethylated glucuronide have been detected in plasma after silymarin administration [28,29]. There are two major glucuronidation sites, C-7 and C-20. Silybin is glucuronidated in a stereoselective manner, with silybin B more efficiently glucuronidated at the C-20 position, while silybin A is glucuronidated similarly on both sites [4] due to the stereoselective activity of certain UGT isoforms [27].

The rapid and extensive phase II metabolism of silybin has been considered as the major reason contributing to its low bioavailability. However, in a group of 56 subjects diagnosed with either HCV or non-alcoholic fatty liver disease (NAFLD), mutant allele UGT1A1*28 produced little inter-subject variability in silybin pharmacokinetics [30]. These data indicate that the role of metabolic enzyme activity is obscured by other more prevalent factors. 

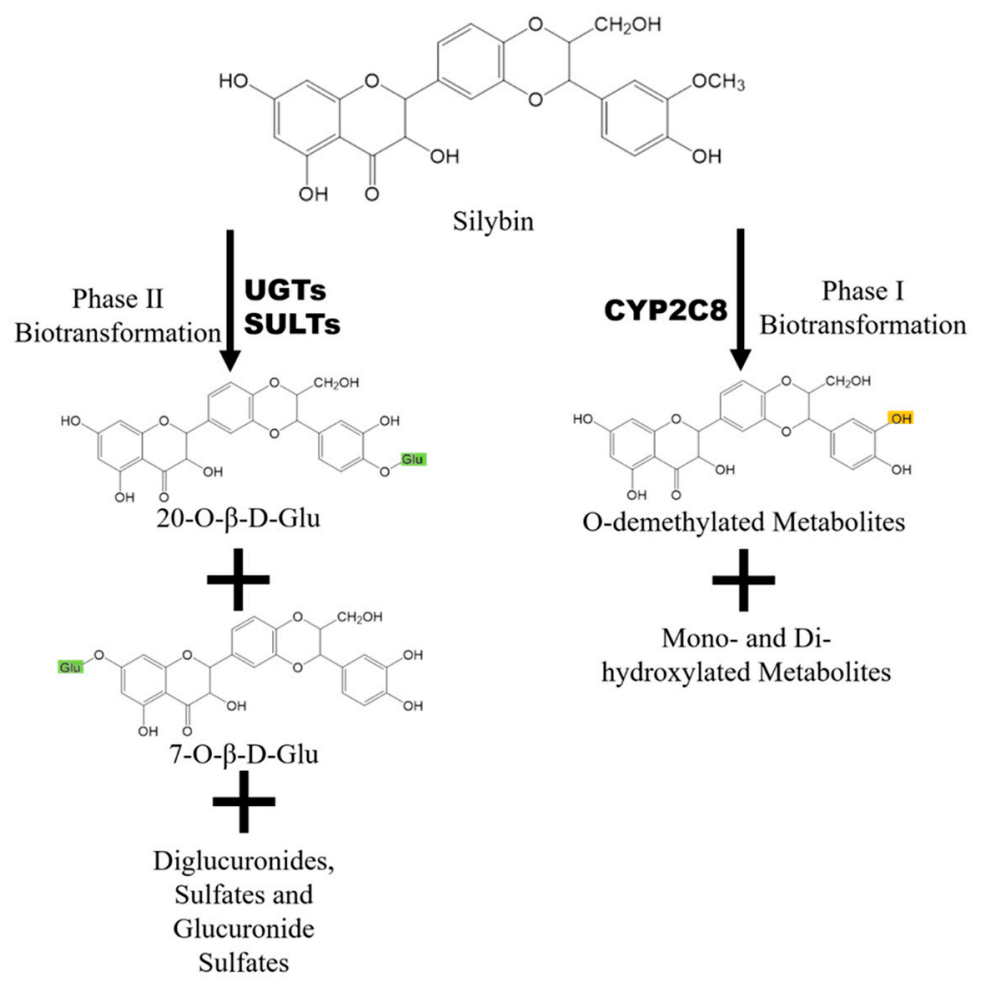

Figure 3. Metabolism of silybin and its major metabolites. UGT: UDP-glucuronosyltransferase; SULTs: sulfotransferases; CYP2C8: Cytochrome P450 2C8.

\subsection{Elimination}

Both free and conjugated silymarin eliminated rapidly in vivo. However, the renal excretion of silybin is low and accounts for only $1-2 \%$ of an original oral dose over $24 \mathrm{~h}$ [31]. Instead, hepatobiliary excretion is extensive, as biliary concentration of silybin was about 100 times higher than serum concentration in patients [31]. Based on an $\mathrm{AUC}_{\text {bile }} / \mathrm{AUC}_{\text {blood }}$ (blood-to-bile distribution ratio) distribution ratio $(30 \pm 9.4)$ of total silybin, silybin was proposed to be excreted into the bile through active transport [32]. As with most flavonoids, the pharmacokinetic behavior of silybin in vivo exhibits a enterohepatic circulation, where excreted glucuronidated silybin undergoes bacterial enzymatic cleavage of $\beta$-glucosidic bonds and is re-absorbed, as indicated by the secondary peak in the plasma concentration curve [21].

Miranda et al. showed that MRP2 was the transporter mainly responsible for the biliary excretion of free and conjugated silybin using perfused rat liver from wild type and MRP2-deficient $\left(\mathrm{TR}^{-}\right)$ Wistar rats [33]. Whether or to what extent BCRP is involved in biliary excretion of silybin remains unknown [23]. By targeting efflux transporters responsible for the excretion and absorption of silybin and its metabolites, researchers demonstrated that bioavailability enhancers, or bio-enhancers, boost bioavailability and pharmacological effects of silybin in vivo.

\section{Silybin as a Beneficiary of DDI}

Previous studies focus extensively on silybin interfering with the metabolism and disposition of other drugs. However, some studies in recent years revealed the likelihood that silybin may be influenced by certain compounds such as tangeretin [23], piperine [34], and baicalein [19]. New formulations of silybin containing these bio-enhancers [35] provide new therapeutic strategy.

\subsection{Tangeretin}

Tangeretin is a flavonoid that mainly exists in citrus fruits, especially in the peel [36]. Yuan et al. found that co-administration of tangeretin not only significantly increased absorption and bioavailability 
of silybin, but also enhanced the hepatoprotective, anti-inflammatory, and antioxidant effect of silybin in a $\mathrm{CCl}_{4}$-induced liver injury rat model. Tangeretin could enhance the intestinal absorption and inhibit the biliary excretion of both free and conjugated silybin based on the data from Caco-2 and sandwich-cultured rat hepatocyte ( $\mathrm{SCH})$ models by inhibiting the efflux transporters MRPs and BCRP [23].

\subsection{Piperine}

Piperine is the main component of black and long pepper that has attracted much attention in recent years for its inhibiting activities on efflux transporters and metabolic enzymes [37]. Bi and colleagues proved that piperine is not only an inhibitor of P-gp, but also an inhibitor of MRP2 and BCRP in Caco-2 model and MDCKII cell lines [34]. When silybin and piperine were co-administered, the maximum plasma drug concentration $\left(C_{\max }\right)$ and the area under the drug concentration-time curve up to time ' $t$ ' $\left(\mathrm{AUC}_{0-\mathrm{t}}\right)$ of both silybin $\mathrm{A}$ and silybin $\mathrm{B}$ in rats were higher than that of silybin used alone [34]. A $76 \%$ increase in $\mathrm{C}_{\max }$ and a $37 \%$ increase in $\mathrm{AUC}_{0-\mathrm{t}}$ of silybin A were observed, while $\mathrm{C}_{\max }$ and $\mathrm{AUC}_{0-\mathrm{t}}$ of total silybin $\mathrm{B}$ were increased by $60 \%$ and $26 \%$, respectively. The concentrations of free silybin A and silybin B were also increased by piperine on a similar scale. MRP2 and BCRP are located on the apical membrane of intestinal epithelial cells and pumped substrates back into the intestine. Therefore, inhibition of MRP2 and BCRP by piperine may be a major reason for the increased exposure of silybin.

\subsection{Baicalein and Baicalin}

Baicalein (5,6,7-trihydroxy-2-phenyl-4H-1-benzopyran-4-one), which mainly exists in the genus Scutellaria, is a flavone with antioxidant activity and other pharmacological activities [38,39]. After oral administration, baicalein is glucuronidated into baicalin and baicalein 6-O-glucuronic acid by the UGT enzyme in either the intestine or the liver [40]. Both baicalein and baicalin are inhibitors of MRP2 and BCRP. Experiments have proved that when silybin and baicalein were administered simultaneously, the $C_{\max }, \mathrm{AUC}_{0-\mathrm{t}}$, and area under the concentration time-curves from time zero to infinity $\left(\mathrm{AUC}_{0-\infty}\right)$ of silybin in rats were increased [19]. However, there might be other factors contributing to this result besides efflux transporter inhibition. Silybin and baicalein may compete for the binding site of the UGT enzyme in vivo [41], resulting in the increase of silybin concentration, which need further studies to confirm. The co-administration of baicalein and silybin showed a synergistic liver protective effects [19], suggesting a potential method for improving the clinical efficacy of silybin.

\section{Silybin as a Perpetrator of DDI}

Modulatory effects on the activity and expression of a wide spectrum of liver microsomal enzymes and efflux transporters were noticed with silybin or silymarin in the literature [42,43]. However, there is still a question as to whether silybin or silymarin have the potential to affect other clinical therapeutic drugs.

\subsection{CYP-Mediated Drug-Drug Interaction}

In vitro incubation revealed weak to moderate inhibition of silybin on most CYP enzymes. Silymarin or silybin inhibit CYP1A2, 2B6, 2C8, 2C9, 2C19, 2D6, and 3A4, but the most prominent inhibition effects are of CYP3A4 and CYP2C9 [42]. Depending on the study, the half maximal inhibitory concentration $\left(\mathrm{IC}_{50}\right)$ for CYP2C9 was reported to be $34 \mu \mathrm{M}$ or $43-45 \mu \mathrm{M}([25,42]$, respectively), and the $\mathrm{IC}_{50}$ for CYP 3A4 was reported to be $27 \mu \mathrm{M}, 49.8 \mu \mathrm{M}$, or $>200 \mu \mathrm{M}$ ([25,42,44], respectively). However, contradictory inhibition results by silybin were observed for the two CYP3A4 substrates denitronifedipine $(29 \mu \mathrm{M})$ and erythromycin $(>200 \mu \mathrm{M})$, which may due to the existence of more than one binding site at CYP3A4 [42]. In general, it is commonly agreed that silybin suppresses the activity of most enzymes, but rarely at a clinically relevant concentration, which is up to $1.5 \mu \mathrm{M}$ [45]. However, one exception, CYP2C9, was found vulnerable to silybin interference at a clinically relevant 
concentration ( $\mathrm{IC}_{50}$ of $8.2 \mu \mathrm{M}$ for silybin $\mathrm{A}$ ), as was claimed in one study with warfarin in human liver microsomes [46]. It still needs confirmation based on data from the clinical study.

As for moderation of CYPs on a transcriptional level, downregulation of CYP 3A4 was only reported in Caco-2 monolayer [47], but not in primary human hepatocytes [48].

Numerous phase I clinical trials were performed to investigate silymarin/silybin-induced drug-drug interaction mainly based on CYP enzymes (Table 1). Aminopyrine and phenylbutazone used as non-specific probes were not affected by Legalon ${ }^{\circledR}$ (silymarin) at $3 \times 70 \mathrm{mg} /$ day in a clinical study [49]. For CYP 3A4-mediated interactions, indinavir [50,51], midazolam [52,53], irinotecan [54], and ranitidine [55] were used as probe drugs. However, there are limited influences on the pharmacokinetics of these drugs, indicating no interaction of silymarin based on CYP 3A4. Similar conclusions were drawn for CYP 2D6 [52,56] and CYP 1A2 [52].

Table 1. List of published clinical trials on silybin-related drug-drug interactions *

\begin{tabular}{|c|c|c|c|c|c|c|}
\hline & Subjects & Silybin Dosing & Probe Drug Dosing & $\begin{array}{c}\text { Enzymes or } \\
\text { Transporters } \\
\text { Involved }\end{array}$ & Conclusion & \\
\hline 2 & $\begin{array}{l}10 \text { healthy } \\
\text { volunteers }\end{array}$ & $\begin{array}{l}175 \text { mg milk thistle } \\
\text { extract, } 3 \text { times daily for } \\
3 \text { weeks }\end{array}$ & indinavir $800 \mathrm{mg} / 8 \mathrm{~h}$ & CYP3A4 & $\begin{array}{l}9 \% \text { reduction in } \\
\text { AUC of indinavir }\end{array}$ & [50] \\
\hline 3 & $\begin{array}{l}10 \text { healthy } \\
\text { volunteers }\end{array}$ & $\begin{array}{l}160 \text { mg silymarin, } \\
3 \text { times/day }\end{array}$ & $\begin{array}{l}\text { indinavir } 800 \mathrm{mg} \\
3 \text { times/day }\end{array}$ & CYP3A4 & No influence & [57] \\
\hline 4 & $\begin{array}{l}16 \text { healthy } \\
\text { volunteers }\end{array}$ & $\begin{array}{l}450 \text { mg milk thistle } \\
\text { extract daily }\end{array}$ & indinavir & CYP3A4 & No influence & {$[51]$} \\
\hline 6 & $\begin{array}{l}12 \text { healthy } \\
\text { volunteers }\end{array}$ & $\begin{array}{l}175 \text { mg (containing 80\% } \\
\text { silymarin) twice daily }\end{array}$ & $\begin{array}{l}\text { midazolam and caffeine, } \\
\text { followed } 24 \mathrm{~h} \text { later by } \\
\text { chlorzoxazone and } \\
\text { debrisoquin }\end{array}$ & $\begin{array}{l}\text { CYP1A2, } \\
\text { CYP2D6, } \\
\text { CYP2E1, } \\
\text { CYP3A4 }\end{array}$ & No influence & [52] \\
\hline 7 & $\begin{array}{l}6 \text { cancer } \\
\text { patients }\end{array}$ & $\begin{array}{l}200 \text { mg milk thistle } \\
\text { (containing } 80 \% \\
\text { silymarin), thrice a day, } \\
\text { for } 14 \text { consecutive days }\end{array}$ & $\begin{array}{c}\text { irinotecan once a week } \\
\text { i.v. } 125 \mathrm{mg} / \mathrm{m}^{2}\end{array}$ & $\begin{array}{l}\text { CYP3A4 } \\
\text { UGT1A1 }\end{array}$ & No influence & [54] \\
\hline 8 & $\begin{array}{l}16 \text { healthy } \\
\text { volunteers }\end{array}$ & $\begin{array}{l}900 \text { mg milk thistle } \\
\text { (containing } 80 \% \\
\text { silymarin) for } 14 \text { days }\end{array}$ & digoxin $0.4 \mathrm{mg}$ & P-gp & No influence & [59] \\
\hline 11 & $\begin{array}{l}12 \text { young } \\
\text { male } \\
\text { volunteers }\end{array}$ & $\begin{array}{c}140 \mathrm{mg} \text { silymarin thrice } \\
\text { daily }\end{array}$ & $150 \mathrm{mg}$ ranitidine & $\begin{array}{l}\text { CYP3A4, } \\
\text { P-gP }\end{array}$ & No influence & [55] \\
\hline 12 & $\begin{array}{l}8 \text { healthy } \\
\text { male } \\
\text { volunteers }\end{array}$ & $\begin{array}{l}140 \text { mg silymarin } \\
4 \text { times daily }\end{array}$ & $10 \mathrm{mg}$ rouvastatin & $\begin{array}{l}\text { OATP1B1, } \\
\text { BCRP }\end{array}$ & No influence & [61] \\
\hline 13 & $\begin{array}{l}16 \text { healthy } \\
\text { volunteers }\end{array}$ & $\begin{array}{l}300 \text { mg milk thistle } \\
\text { extract (containing } 80 \% \\
\text { silymarin) } 3 \text { times daily }\end{array}$ & $5 \mathrm{mg}$ debrisoquine & CYP2D6 & No influence & [56] \\
\hline 14 & $\begin{array}{l}18 \text { healthy } \\
\text { adult men }\end{array}$ & $\begin{array}{l}140 \text { mg silymarin } \\
3 \text { times daily for } 14 \text { days }\end{array}$ & talinolol & P-gp & $\begin{array}{l}\text { Silymarin increased } \\
(36 \%) \text { AUC of } \\
\text { talinolol }\end{array}$ & [62] \\
\hline
\end{tabular}


Table 1. Cont.

\begin{tabular}{|c|c|c|c|c|c|c|}
\hline & Subjects & Silybin Dosing & Probe Drug Dosing & $\begin{array}{c}\text { Enzymes or } \\
\text { Transporters } \\
\text { Involved }\end{array}$ & Conclusion & \\
\hline 15 & $\begin{array}{l}12 \text { healthy } \\
\text { adult men }\end{array}$ & $\begin{array}{l}140 \text { mg silymarin } \\
3 \text { times daily }\end{array}$ & losartan & СYP2C9 & $\begin{array}{l}\text { Inhibition CYP2C9 } \\
\text { in a genotype- } \\
\text { dependent manner }\end{array}$ & [63] \\
\hline 16 & $\begin{array}{c}15 \\
\text { HIV-infected } \\
\text { patients }\end{array}$ & $\begin{array}{l}150 \text { mg silymarin } \\
3 \text { times daily }\end{array}$ & $\begin{array}{c}\text { darunavir-ritonavir } \\
\text { (600/100 mg twice daily) }\end{array}$ & $\begin{array}{l}\text { CYP3A4, } \\
\text { P-gp }\end{array}$ & $\begin{array}{c}\text { Silymarin slightly } \\
\text { decreased }(15 \%) \text { the } \\
\text { AUC of } \\
\text { darunavir-ritonavir }\end{array}$ & [64] \\
\hline 17 & $\begin{array}{l}8 \text { healthy } \\
\text { male } \\
\text { volunteers }\end{array}$ & $\begin{array}{l}500 \text { mg silymarin twice } \\
\text { daily for } 7 \text { days }\end{array}$ & 10 mg domperidon & $\begin{array}{l}\text { CYP3A4, } \\
\text { P-gp }\end{array}$ & $\begin{array}{c}\text { Silymarin } \\
\text { pretreatment } \\
\text { increased AUC of } \\
\text { domperidone by } \\
\text { 5-fold. }\end{array}$ & [65] \\
\hline 18 & $\begin{array}{l}9 \text { healthy } \\
\text { volunteers }\end{array}$ & $\begin{array}{l}175 \text { mg Legalon }{ }^{\circledR} \\
\text { (140 mg silymarin) } \\
\text { thrice daily for } 14 \text { days }\end{array}$ & $\begin{array}{c}\text { caffeine, tolbutamide, } \\
\text { dextromethorphan, } \\
\text { midazolam }\end{array}$ & $\begin{array}{l}\text { CYP1A2, } \\
\text { CYP2C9, } \\
\text { CYP2D6, } \\
\text { CYP3A4/5 }\end{array}$ & No influence & [66] \\
\hline
\end{tabular}

\footnotetext{
* Notes: only papers with the keyword silybin or silymarin, milk thistle, Silybum marianum, and silibinin in their titles were searched, which yielded 82 results. Among the 82 items only 18 studies satisfied our criteria as clinical trials studying the effects of silybin or silymarin on the pharmacokinetics of other drugs, and were organized into this table that displays their dosing regimens, probe drugs, enzymes or transporters that they studied, and conclusions. We noticed that clinical research on silybin drug-drug interactions (DDIs) has stagnated since 2014. As for dosing of silybin, dosing regimens range from an equivalence of $140 \mathrm{mg}$ of standardized silymarin daily to 900 mg daily. Study designs include both crossover studies and parallel designs, either open-labeled or blinded. AUC: area under the plasma drug concentration-t curve; BCRP: breast cancer resistance protein; P-gp: P-glycoprotein; OATP: organic-anion-transporting polypeptide, CYP: cytochrome P-450; i.v.: Intravenous perfusion.
}

Despite clinical trials disproving interactions, animal experiments kept raising alarm. In rabbits, pretreatment but not co-administration of $50 \mathrm{mg} / \mathrm{kg}$ oral silybin increased nitrendipine (mostly metabolized by CYP3A4), area under the plasma drug concentration-t curve (AUC), and $\mathrm{C}_{\max }$ [67]. A more recent study in rats observed an elevated exposure of the central analgesic methadone (mostly metabolized by CYP3A4) associated with pre-treatment of silybin [68].

In conclusion, silybin inhibits CYP enzymes, with 2C9 and 3A4 being the most sensitive, but rarely at clinically achievable concentrations. Thus, CYP-mediated DDI for silybin is not a major clinical concern, though sensitive drugs such as warfarin, opioids, and anti-arrhythmic agents require attention.

\subsection{UGT-Mediated Drug-Drug Interaction}

In comparison with CYPs, UGTs are generally more vulnerable to inhibition in the presence of silybin in in vitro environment. It was confirmed in Raman's study that UGT 1A6/9 activity was reduced after silymarin treatment at a relatively high concentration of $0.1 \mathrm{mM}$ [69]. However, Sirdar discovered that silybin is a potent inhibitor of recombinant UGT1A1, with an $\mathrm{IC}_{50}$ of only $1.4 \mu \mathrm{M}$, which is more selective than UGT 1A6/9 [70]. However, the clinical significance for inhibiting UGT1A1 was not clear.

Among these drug-drug interaction clinical trials associated with concomitant dosing of silybin or silymarin, however, few were carried out with UGT substrates (Table 1). There is only one study in which a dose of $3 \times 200 \mathrm{mg} /$ day milk thistle preparation (containing $80 \%$ silymarin) was given to six cancer patients receiving irinotecan therapy for 14 consecutive days [54]. No influence was observed on the pharmacokinetics of irinotecan after either short-term or long-term exposure of silybin in the form of milk thistle. However, the current clinical evidence cannot warrant that silybin has no interaction with UGT-metabolized drugs based on the limited data. 


\subsection{DDI Mediated by Transporters}

Köch et al. discovered of the potent inhibition to the organic anion-transporting polypeptides (OATP) transporter family including OATP1B1, OATP1B3, and OATP2B1 by silymarin. However, the $\mathrm{IC}_{50}$ values of silymarin or silybin for OATPs were far below their portal vein concentrations in vivo, indicating that silymarin-drug interactions via inhibition of OATPs are unlikely to happen in clinical conditions with a customary dose [71].

Nguyen's study showed that silybin reduced the efflux of two substrates of P-gp including digoxin and vinblastine in Panc-1 cells, indicating the inhibiting effect of silybin to P-gp [72]. However, most of the studies about P-gp inhibition by silybin or silymarin are pre-clinical studies with cells or animals. In fact, the results of the related clinical studies were complex. Gurley's group revealed that milk thistle (containing 80\% silymarin) at a dose given daily of $900 \mathrm{mg}$ does not affect P-gp substrate digoxin [59] in terms of clinical related physiological parameters. However, Han's group showed that silymarin significantly increased the plasma concentration of talinolol, which is also a typical substrate of P-gp, in healthy volunteers [62]. In contrast, Rajnarayana's group found that silymarin increased the clearance of metronidazole with a concomitant decrease in half-life, $C_{\max }$, and AUC, as silymarin might induce both intestinal P-gp and CYP3A4 upon multiple-dose administration [58]. These variations may be due to many factors such as formulation, dose, frequency of administration, statistical methods, and so on.

\section{Conclusions and Outlook}

It is commonly viewed that silybin is well tolerated with few side effects, and has significant anti-inflammatory, antiviral, antioxidant, and anticancer activities. Silymarin, silybin, and milk thistle extract currently rank among the top-selling botanical supplements or phytomedicines. However, the clinical outcomes of the hepatoprotection effects are varied for silymarin, mainly caused by its low bioavailability. As a hepatoprotective agent, it is frequently prescribed as an adjuvant therapy along with other medications such as methotrexate, which has significant liver toxicity [73]. Therefore, it is necessary to understand the metabolism and/or transport of silymarin as well as the risk of DDI associated with the process.

Studies have shown that drugs inhibiting BCRP and MRP2, such as piperine or tangeretin [23,34], may lead to increased bioavailability of silybin. Similarly, enhanced-exposure of silybin occurred in patients with hepatic cirrhosis where transporter expression is also known to decrease [74]. However, mutant allele UGT1A ${ }^{*} 28$ produced little inter-subject variability in silybin pharmacokinetics [30]. Such increased silybin exposure is a result of silybin accumulation via efflux transport inhibition because of drug-drug interaction but is not related to the UGT enzyme.

From another point of view, our current findings on drug-drug interactions of silymarin, especially results from clinical trials, concluded that silymarin does not pose a clinically relevant risk of drug-drug interaction. Although silymarin does inhibit activities of enzymes and transporters concerned with the pharmacokinetics of therapeutic drugs, its concentration within the human body rarely reaches the point that constitutes significant inhibition due to low bioavailability of silymarin [45].

However, exceptions do exist. Pharmacokinetic studies carried out in healthy volunteers indicated that silymarin pretreatment increased the exposure of talinolol [62] and domperidone [65], but decreased the AUC of indinavir [57] and metronidazole [58]. In another study conducted with losartan, it was claimed that losartan biotransformation into its active form was significantly decreased by silybin administration, with the CYP2C $9^{*} 1 /{ }^{*} 1$ genotype more affected than the $2 \mathrm{C} 9^{*} 1 /{ }^{*} 3$ genotype [63]. Silybin also affects the pharmacokinetics of pyrazinamide, a chemotherapeutic agent for tuberculosis in rats [75]. These results remind us that the likelihood of DDI induced by silymarin/silybin persists, especially with certain sensitive drugs.

Since inconsistent results have been noted in different clinical studies regarding risks of DDI with medications such indinavir, further clinical studies are needed to investigate the impacts of pharmacogenetic factors, the pathological state of patients, and transporters. In addition, guidelines should be established for identifying drugs with potential silymarin-induced DDIs. 
Author Contributions: Conceptualization and design: Y.X.; Investigation and original draft preparation: D.Z., J.Z. and J.Y.; Review and proofreading of the paper: Y.X. and D.Z.; Final review and approval of the manuscript: all authors.

Funding: This work was financially funded by The Science and Technology Development Fund, Macau SAR (File no. 003/2017/A1).

Conflicts of Interest: The authors have no conflict of interest to declare.

\section{Abbreviations}

$\begin{array}{ll}\text { AUC } & \text { area under the plasma drug concentration-t curve } \\ \text { BCRP } & \text { Breast Cancer Resistance Protein } \\ \text { C }_{\max } & \text { Maximum plasma drug concentration } \\ \text { CYPs } & \text { Cytochromes P450 } \\ \text { DDI } & \text { Drug-drug interaction } \\ \text { IC }_{50} & \text { The half maximal inhibitory concentration } \\ \text { MDCK cells } & \text { Madin-Darby canine kidney cells } \\ \text { MRPs } & \text { Multidrug resistance-associated protein } \\ \text { OATP } & \text { Organic-anion-transporting polypeptide } \\ \text { P-gp } & \text { P-glycoprotein } \\ \text { SULTs } & \text { sulfotransferases } \\ \text { UGT } & \text { UDP-glucuronosyltransferase }\end{array}$

\section{References}

1. Bijak, M. Silybin. a Major Bioactive Component of Milk Thistle (Silybum marianum L. Gaernt.) —Chemistry, Bioavailability, and Metabolism. Molecules 2017, 22, 1942. [CrossRef] [PubMed]

2. Rainone, F. Milk thistle. Am. Fam. Physician 2005, 72, 1285-1288. [PubMed]

3. Lee, J.I.; Narayan, M.; Barrett, J.S. Analysis and comparison of active constituents in commercial standardized silymarin extracts by liquid chromatography-electrospray ionization mass spectrometry. J. Chromatogr. B Anal. Technol. Biomed. Life Sci. 2007, 845, 95-103. [CrossRef] [PubMed]

4. Han, Y.H.; Lou, H.X.; Ren, D.M.; Sun, L.R.; Ma, B.; Ji, M. Stereoselective metabolism of silybin diastereoisomers in the glucuronidation process. J. Pharm. Biomed. Anal. 2004, 34, 1071-1078. [CrossRef] [PubMed]

5. Kim, N.C.; Graf, T.N.; Sparacino, C.M.; Wani, M.C.; Wall, M.E. Complete isolation and characterization of silybins and isosilybins from milk thistle (Silybum marianum). Org. Biomol. Chem. 2003, 1, 1684-1689. [CrossRef] [PubMed]

6. Federico, A.; Dallio, M.; Loguercio, C. Silymarin/Silybin and Chronic Liver Disease: A Marriage of Many Years. Molecules 2017, 22, 191. [CrossRef] [PubMed]

7. Abenavoli, L.; Izzo, A.A.; Milic, N.; Cicala, C.; Santini, A.; Capasso, R. Milk thistle (Silybum marianum): A concise overview on its chemistry, pharmacological, and nutraceutical uses in liver diseases. Phytother. Res. 2018, 32, 2202-2213. [CrossRef]

8. Surai, P.F. Silymarin as a Natural Antioxidant: An Overview of the Current Evidence and Perspectives. Antioxid. (BaselSwitz.) 2015, 4, 204-247. [CrossRef]

9. Soleimani, V.; Delghandi, P.S.; Moallem, S.A.; Karimi, G. Safety and toxicity of silymarin, the major constituent of milk thistle extract: An updated review. Phytother. Res. 2019, 33, 1627-1638. [CrossRef]

10. Matsuda, T.; Ferreri, K.; Todorov, I.; Kuroda, Y.; Smith, C.V.; Kandeel, F.; Mullen, Y. Silymarin protects pancreatic beta-cells against cytokine-mediated toxicity: Implication of c-Jun NH2-terminal kinase and janus kinase/signal transducer and activator of transcription pathways. Endocrinology 2005, 146, 175-185. [CrossRef]

11. Fallahzadeh, M.K.; Dormanesh, B.; Sagheb, M.M.; Roozbeh, J.; Vessal, G.; Pakfetrat, M.; Daneshbod, Y.; Kamali-Sarvestani, E.; Lankarani, K.B. Effect of addition of silymarin to renin-angiotensin system inhibitors on proteinuria in type 2 diabetic patients with overt nephropathy: A randomized, double-blind, placebo-controlled trial. Am. J. Kidney Dis. 2012, 60, 896-903. [CrossRef] [PubMed] 
12. Raina, K.; Rajamanickam, S.; Singh, R.P.; Deep, G.; Chittezhath, M.; Agarwal, R. Stage-specific inhibitory effects and associated mechanisms of silibinin on tumor progression and metastasis in transgenic adenocarcinoma of the mouse prostate model. Cancer Res. 2008, 68, 6822-6830. [CrossRef] [PubMed]

13. Chakrabarti, M.; Ray, S.K. Anti-tumor activities of luteolin and silibinin in glioblastoma cells: Overexpression of miR-7-1-3p augmented luteolin and silibinin to inhibit autophagy and induce apoptosis in glioblastoma in vivo. Apoptosis 2016, 21, 312-328. [CrossRef] [PubMed]

14. Jahanafrooz, Z.; Motamed, N.; Rinner, B.; Mokhtarzadeh, A.; Baradaran, B. Silibinin to improve cancer therapeutic, as an apoptotic inducer, autophagy modulator, cell cycle inhibitor, and microRNAs regulator. Life Sci. 2018, 213, 236-247. [CrossRef]

15. Sciacca, M.F.M.; Romanucci, V.; Zarrelli, A.; Monaco, I.; Lolicato, F.; Spinella, N.; Galati, C.; Grasso, G.; D'Urso, L.; Romeo, M.; et al. Inhibition of A $\beta$ Amyloid Growth and Toxicity by Silybins: The Crucial Role of Stereochemistry. ACS Chem. Neurosci. 2017, 8, 1767-1778. [CrossRef]

16. Sciacca, M.F.M.; Tempra, C.; Scollo, F.; Milardi, D.; La Rosa, C. Amyloid growth and membrane damage: Current themes and emerging perspectives from theory and experiments on Abeta and hIAPP. Biochim. Biophys. Acta Biomembr. 2018. [CrossRef]

17. Fried, M.W.; Navarro, V.J.; Afdhal, N.; Belle, S.H.; Wahed, A.S.; Hawke, R.L.; Doo, E.; Meyers, C.M.; Reddy, K.R. Effect of silymarin (milk thistle) on liver disease in patients with chronic hepatitis $\mathrm{C}$ unsuccessfully treated with interferon therapy: A randomized controlled trial. Jama 2012, 308, 274-282. [CrossRef]

18. Loguercio, C.; Festi, D. Silybin and the liver: From basic research to clinical practice. World J. Gastroenterol. 2011, 17, 2288-2301. [CrossRef]

19. Xu, P.; Zhou, H.; Li, Y.Z.; Yuan, Z.W.; Liu, C.X.; Liu, L.; Xie, Y. Baicalein Enhances the Oral Bioavailability and Hepatoprotective Effects of Silybin Through the Inhibition of Efflux Transporters BCRP and MRP2. Front. Pharm. 2018, 9, 1115. [CrossRef]

20. Javed, S.; Kohli, K.; Ali, M. Reassessing bioavailability of silymarin. Altern. Med. Rev. A J. Clin. Ther. 2011, 16, 239-249.

21. Wen, Z.; Dumas, T.E.; Schrieber, S.J.; Hawke, R.L.; Fried, M.W.; Smith, P.C. Pharmacokinetics and metabolic profile of free, conjugated, and total silymarin flavonolignans in human plasma after oral administration of milk thistle extract. Drug Metab. Dispos. Biol. Fate Chem. 2008, 36, 65-72. [CrossRef] [PubMed]

22. Schrieber, S.J.; Wen, Z.; Vourvahis, M.; Smith, P.C.; Fried, M.W.; Kashuba, A.D.; Hawke, R.L. The pharmacokinetics of silymarin is altered in patients with hepatitis $C$ virus and nonalcoholic Fatty liver disease and correlates with plasma caspase-3/7 activity. Drug Metab. Dispos. Biol. Fate Chem. 2008, 36, 1909-1916. [CrossRef] [PubMed]

23. Yuan, Z.W.; Li, Y.Z.; Liu, Z.Q.; Feng, S.L.; Zhou, H.; Liu, C.X.; Liu, L.; Xie, Y. Role of tangeretin as a potential bioavailability enhancer for silybin: Pharmacokinetic and pharmacological studies. Pharmacol. Res. 2018, 128, 153-166. [CrossRef] [PubMed]

24. Kren, V.; Marhol, P.; Purchartova, K.; Gabrielova, E.; Modriansky, M. Biotransformation of silybin and its congeners. Curr. Drug Metab. 2013, 14, 1009-1021. [CrossRef] [PubMed]

25. Jancova, P.; Anzenbacherova, E.; Papouskova, B.; Lemr, K.; Luzna, P.; Veinlichova, A.; Anzenbacher, P.; Simanek, V. Silybin is metabolized by cytochrome P450 2C8 in vitro. Drug Metab. Dispos. 2007, 35, 2035-2039. [CrossRef]

26. Gunaratna, C.; Zhang, T. Application of liquid chromatography-electrospray ionization-ion trap mass spectrometry to investigate the metabolism of silibinin in human liver microsomes. J. Chromatogr B Anal. Technol. Biomed. Life Sci. 2003, 794, 303-310. [CrossRef]

27. Jancova, P.; Siller, M.; Anzenbacherova, E.; Kren, V.; Anzenbacher, P.; Simanek, V. Evidence for differences in regioselective and stereoselective glucuronidation of silybin diastereomers from milk thistle (Silybum marianum) by human UDP-glucuronosyltransferases. Xenobiotica 2011, 41, 743-751. [CrossRef]

28. Hoh, C.S.; Boocock, D.J.; Marczylo, T.H.; Brown, V.A.; Cai, H.; Steward, W.P.; Berry, D.P.; Gescher, A.J. Quantitation of silibinin, a putative cancer chemopreventive agent derived from milk thistle (Silybum marianum), in human plasma by high-performance liquid chromatography and identification of possible metabolites. J. Agric. Food Chem. 2007, 55, 2532-2535. [CrossRef] 
29. Hoh, C.; Boocock, D.; Marczylo, T.; Singh, R.; Berry, D.P.; Dennison, A.R.; Hemingway, D.; Miller, A.; West, K.; Euden, S.; et al. Pilot study of oral silibinin, a putative chemopreventive agent, in colorectal cancer patients: Silibinin levels in plasma, colorectum, and liver and their pharmacodynamic consequences. Clin. Cancer Res. 2006, 12, 2944-2950. [CrossRef]

30. Xie, Y.; Miranda, S.R.; Hoskins, J.M.; Hawke, R.L. Role of UDP-Glucuronosyltransferase 1A1 in the Metabolism and Pharmacokinetics of Silymarin Flavonolignans in Patients with HCV and NAFLD. Molecules 2017, 22, 142. [CrossRef]

31. Lorenz, D.; Lucker, P.W.; Mennicke, W.H.; Wetzelsberger, N. Pharmacokinetic studies with silymarin in human serum and bile. Methods Find. Exp. Clin. Pharm. 1984, 6, 655-661.

32. Wu, J.W.; Lin, L.C.; Hung, S.C.; Chi, C.W.; Tsai, T.H. Analysis of silibinin in rat plasma and bile for hepatobiliary excretion and oral bioavailability application. J. Pharm. Biomed. Anal. 2007, 45, 635-641. [CrossRef] [PubMed]

33. Miranda, S.R.; Lee, J.K.; Brouwer, K.L.; Wen, Z.; Smith, P.C.; Hawke, R.L. Hepatic metabolism and biliary excretion of silymarin flavonolignans in isolated perfused rat livers: Role of multidrug resistance-associated protein 2 (Abcc2). Drug Metab. Dispos. Biol. Fate Chem. 2008, 36, 2219-2226. [CrossRef] [PubMed]

34. Bi, X.; Yuan, Z.; Qu, B.; Zhou, H.; Liu, Z.; Xie, Y. Piperine enhances the bioavailability of silybin via inhibition of efflux transporters BCRP and MRP2. Phytomedicine 2019, 54, 98-108. [CrossRef]

35. Kesarwani, K.; Gupta, R.; Mukerjee, A. Bioavailability enhancers of herbal origin: An overview. Asian Pac. J. Trop. Biomed. 2013, 3, 253-266. [CrossRef]

36. Hung, W.L.; Chang, W.S.; Lu, W.C.; Wei, G.J.; Wang, Y.; Ho, C.T.; Hwang, L.S. Pharmacokinetics, bioavailability, tissue distribution and excretion of tangeretin in rat. J. Food Drug Anal. 2018, 26, 849-857. [CrossRef]

37. Lee, S.H.; Kim, H.Y.; Back, S.Y.; Han, H.K. Piperine-mediated drug interactions and formulation strategy for piperine: Recent advances and future perspectives. Expert Opin. Drug Metab. Toxicol. 2018, 14, 43-57. [CrossRef]

38. Woo, A.Y.; Cheng, C.H.; Waye, M.M. Baicalein protects rat cardiomyocytes from hypoxia/reoxygenation damage via a prooxidant mechanism. Cardiovasc. Res. 2005, 65, 244-253. [CrossRef]

39. Bie, B.; Sun, J.; Guo, Y.; Li, J.; Jiang, W.; Yang, J.; Huang, C.; Li, Z. Baicalein: A review of its anti-cancer effects and mechanisms in Hepatocellular Carcinoma. Biomed. Pharm. 2017, 93, 1285-1291. [CrossRef]

40. Lai, M.Y.; Hsiu, S.L.; Tsai, S.Y.; Hou, Y.C.; Chao, P.D. Comparison of metabolic pharmacokinetics of baicalin and baicalein in rats. J. Pharm. Pharm. 2003, 55, 205-209. [CrossRef]

41. Zhang, L.; Lin, G.; Zuo, Z. Involvement of UDP-glucuronosyltransferases in the extensive liver and intestinal first-pass metabolism of flavonoid baicalein. Pharm. Res. 2007, 24, 81-89. [CrossRef] [PubMed]

42. Beckmann-Knopp, S.; Rietbrock, S.; Weyhenmeyer, R.; Bocker, R.H.; Beckurts, K.T.; Lang, W.; Hunz, M.; Fuhr, U. Inhibitory effects of silibinin on cytochrome P-450 enzymes in human liver microsomes. Pharmacol. Toxicol. 2000, 86, 250-256. [CrossRef] [PubMed]

43. Wu, J.W.; Lin, L.C.; Tsai, T.H. Drug-drug interactions of silymarin on the perspective of pharmacokinetics. J. Ethnopharmacol. 2009, 121, 185-193. [CrossRef] [PubMed]

44. Zuber, R.; Modriansky, M.; Dvorak, Z.; Rohovsky, P.; Ulrichova, J.; Simanek, V.; Anzenbacher, P. Effect of silybin and its congeners on human liver microsomal cytochrome P450 activities. Phytother. Res. 2002, 16, 632-638. [CrossRef] [PubMed]

45. Gurley, B.J.; Fifer, E.K.; Gardner, Z. Pharmacokinetic herb-drug interactions (part 2): Drug interactions involving popular botanical dietary supplements and their clinical relevance. Planta Med. 2012, 78, 1490-1514. [CrossRef] [PubMed]

46. Brantley, S.J.; Oberlies, N.H.; Kroll, D.J.; Paine, M.F. Two flavonolignans from milk thistle (Silybum marianum) inhibit CYP2C9-mediated warfarin metabolism at clinically achievable concentrations. J. Pharm. Exp. 2010, 332, 1081-1087. [CrossRef]

47. Budzinski, J.W.; Trudeau, V.L.; Drouin, C.E.; Panahi, M.; Arnason, J.T.; Foster, B.C. Modulation of human cytochrome P450 3A4 (CYP3A4) and P-glycoprotein (P-gp) in Caco-2 cell monolayers by selected commercial-source milk thistle and goldenseal products. Can. J. Physiol. Pharm. 2007, 85, 966-978. [CrossRef]

48. Kosina, P.; Maurel, P.; Ulrichova, J.; Dvorak, Z. Effect of silybin and its glycosides on the expression of cytochromes P450 1A2 and 3A4 in primary cultures of human hepatocytes. J. Biochem. Mol. Toxicol. 2005, 19, 149-153. [CrossRef] 
49. Leber, H.W.; Knauff, S. Influence of silymarin on drug metabolizing enzymes in rat and man. Arzneimittelforschung 1976, 26, 1603-1605.

50. Piscitelli, S.C.; Formentini, E.; Burstein, A.H.; Alfaro, R.; Jagannatha, S.; Falloon, J. Effect of milk thistle on the pharmacokinetics of indinavir in healthy volunteers. Pharmacotherapy 2002, 22, 551-556. [CrossRef]

51. Mills, E.; Wilson, K.; Clarke, M.; Foster, B.; Walker, S.; Rachlis, B.; DeGroot, N.; Montori, V.M.; Gold, W.; Phillips, E.; et al. Milk thistle and indinavir: A randomized controlled pharmacokinetics study and meta-analysis. Eur. J. Clin. Pharm. 2005, 61, 1-7. [CrossRef] [PubMed]

52. Gurley, B.J.; Gardner, S.F.; Hubbard, M.A.; Williams, D.K.; Gentry, W.B.; Carrier, J.; Khan, I.A.; Edwards, D.J.; Shah, A. In vivo assessment of botanical supplementation on human cytochrome P450 phenotypes: Citrus aurantium, Echinacea purpurea, milk thistle, and saw palmetto. Clin. Pharm. 2004, 76, 428-440.

53. Gurley, B.; Hubbard, M.A.; Williams, D.K.; Thaden, J.; Tong, Y.; Gentry, W.B.; Breen, P.; Carrier, D.J.; Cheboyina, S. Assessing the clinical significance of botanical supplementation on human cytochrome P450 3A activity: Comparison of a milk thistle and black cohosh product to rifampin and clarithromycin. J. Clin. Pharm. 2006, 46, 201-213. [CrossRef] [PubMed]

54. van Erp, N.P.; Baker, S.D.; Zhao, M.; Rudek, M.A.; Guchelaar, H.J.; Nortier, J.W.; Sparreboom, A.; Gelderblom, H. Effect of milk thistle (Silybum marianum) on the pharmacokinetics of irinotecan. Clin. Cancer Res. 2005, 11, 7800-7806. [CrossRef] [PubMed]

55. Rao, B.N.; Srinivas, M.; Kumar, Y.S.; Rao, Y.M. Effect of silymarin on the oral bioavailability of ranitidine in healthy human volunteers. Drug Metab. Drug Interact. 2007, 22, 175-185. [CrossRef]

56. Gurley, B.J.; Swain, A.; Hubbard, M.A.; Williams, D.K.; Barone, G.; Hartsfield, F.; Tong, Y.; Carrier, D.J.; Cheboyina, S.; Battu, S.K. Clinical assessment of CYP2D6-mediated herb-drug interactions in humans: Effects of milk thistle, black cohosh, goldenseal, kava kava, St. John's wort, and Echinacea. Mol. Nutr. Food Res. 2008, 52, 755-763. [CrossRef]

57. DiCenzo, R.; Shelton, M.; Jordan, K.; Koval, C.; Forrest, A.; Reichman, R.; Morse, G. Coadministration of milk thistle and indinavir in healthy subjects. Pharmacotherapy 2003, 23, 866-870. [CrossRef]

58. Rajnarayana, K.; Reddy, M.S.; Vidyasagar, J.; Krishna, D.R. Study on the influence of silymarin pretreatment on metabolism and disposition of metronidazole. Arzneim. -Forsch. 2004, 54, 109-113. [CrossRef]

59. Gurley, B.J.; Barone, G.W.; Williams, D.K.; Carrier, J.; Breen, P.; Yates, C.R.; Song, P.F.; Hubbard, M.A.; Tong, Y.; Cheboyina, S. Effect of milk thistle (Silybum marianum) and black cohosh (Cimicifuga racemosa) supplementation on digoxin pharmacokinetics in humans. Drug Metab. Dispos. 2006, 34, 69-74. [CrossRef]

60. Fuhr, U.; Beckmann-Knopp, S.; Jetter, A.; Luck, H.; Mengs, U. The effect of silymarin on oral nifedipine pharmacokinetics. Planta Med. 2007, 73, 1429-1435. [CrossRef]

61. Deng, J.W.; Shon, J.H.; Shin, H.J.; Park, S.J.; Yeo, C.W.; Zhou, H.H.; Song, I.S.; Shin, J.G. Effect of silymarin supplement on the pharmacokinetics of rosuvastatin. Pharm. Res. 2008, 25, 1807-1814. [CrossRef]

62. Han, Y.; Guo, D.; Chen, Y.; Tan, Z.R.; Zhou, H.H. Effect of continuous silymarin administration on oral talinolol pharmacokinetics in healthy volunteers. Xenobiotica Fate Foreign Compd. Biol. Syst. 2009, 39, 694-699. [CrossRef]

63. Han, Y.; Guo, D.; Chen, Y.; Tan, Z.R.; Zhou, H.H. Effect of silymarin on the pharmacokinetics of losartan and its active metabolite E-3174 in healthy Chinese volunteers. Eur. J. Clin. Pharm. 2009, 65, 585-591. [CrossRef]

64. Molto, J.; Valle, M.; Miranda, C.; Cedeno, S.; Negredo, E.; Clotet, B. Effect of milk thistle on the pharmacokinetics of darunavir-ritonavir in HIV-infected patients. Antimicrob. Agents Chemother. 2012, 56, 2837-2841. [CrossRef]

65. Yamsani, S.K.; Yamsani, M.R. Effect of silymarin pretreatment on the bioavailability of domperidone in healthy human volunteers. Drug Metab. Drug Interact. 2014, 29, 261-267. [CrossRef]

66. Kawaguchi-Suzuki, M.; Frye, R.F.; Zhu, H.J.; Brinda, B.J.; Chavin, K.D.; Bernstein, H.J.; Markowitz, J.S. The effects of milk thistle (Silybum marianum) on human cytochrome P450 activity. Drug Metab. Dispos. Biol. Fate Chem. 2014, 42, 1611-1616. [CrossRef]

67. Voruganti, S.; Yamsani, S.K.; Yamsani, M.R. Effect of silibinin on the pharmacokinetics of nitrendipine in rabbits. Eur. J. Drug Metab. Pharm. 2014, 39, 277-281. [CrossRef]

68. Pan, P.P.; Wang, J.; Luo, J.; Wang, S.H.; Zhou, Y.F.; Chen, S.Z.; Du, Z. Silibinin affects the pharmacokinetics of methadone in rats. Drug Test. Anal. 2018, 10, 557-561. [CrossRef] 
69. Venkataramanan, R.; Ramachandran, V.; Komoroski, B.J.; Zhang, S.; Schiff, P.L.; Strom, S.C. Milk thistle, a herbal supplement, decreases the activity of CYP3A4 and uridine diphosphoglucuronosyl transferase in human hepatocyte cultures. Drug Metab. Dispos. 2000, 28, 1270-1273.

70. Sridar, C.; Goosen, T.C.; Kent, U.M.; Williams, J.A.; Hollenberg, P.F. Silybin inactivates cytochromes P450 3A4 and 2C9 and inhibits major hepatic glucuronosyltransferases. Drug Metab. Dispos. 2004, 32, 587-594. [CrossRef]

71. Kock, K.; Xie, Y.; Hawke, R.L.; Oberlies, N.H.; Brouwer, K.L. Interaction of silymarin flavonolignans with organic anion-transporting polypeptides. Drug Metab. Dispos. Biol. Fate Chem. 2013, 41, 958-965. [CrossRef]

72. Nguyen, H.; Zhang, S.; Morris, M.E. Effect of flavonoids on MRP1-mediated transport in Panc-1 cells. J. Pharm. Sci. 2003, 92, 250-257. [CrossRef]

73. Hussain, S.A.; Marouf, B.H. Silibinin improves the cytotoxicity of methotrexate in chemo resistant human rhabdomyosarcoma cell lines. Saudi Med. J. 2013, 34, 1145-1150.

74. Wang, L.; Collins, C.; Kelly, E.J.; Chu, X.; Ray, A.S.; Salphati, L.; Xiao, G.; Lee, C.; Lai, Y.; Liao, M.; et al. Transporter Expression in Liver Tissue from Subjects with Alcoholic or Hepatitis C Cirrhosis Quantified by Targeted Quantitative Proteomics. Drug Metab. Dispos. 2016, 44, 1752-1758. [CrossRef]

75. Wu, J.W.; Tsai, T.H. Effect of silibinin on the pharmacokinetics of pyrazinamide and pyrazinoic acid in rats. Drug Metab. Dispos. 2007, 35, 1603-1610. [CrossRef]

(C) 2019 by the authors. Licensee MDPI, Basel, Switzerland. This article is an open access article distributed under the terms and conditions of the Creative Commons Attribution (CC BY) license (http://creativecommons.org/licenses/by/4.0/). 